\title{
Deciphering Oxidative Stress Responsive microRNA (miRNA) in Hilsa (Tenualosa ilisha) and Rohu (Labeo rohita)
}

\author{
Jakir Hossain ${ }^{1,4}$, Mohammad Shahneawz Khan $^{1}$, Salma Akter ${ }^{1, *}$ (D), Md. Golam \\ Rabbane $^{1}$, Haseena Khan ${ }^{2}$, Goutam Kumar Kundu ${ }^{1,3}$, Bijoya Paul ${ }^{1}$ \\ ${ }^{1}$ University of Dhaka, Department of Fisheries, Bangladesh \\ ${ }^{2}$ University of Dhaka, Department of Biochemistry and Molecular Biology, Bangladesh \\ ${ }^{3}$ Gwangju Institute of Science and Technology, School of Earth Sciences and Environmental Engineering, Gwangju, \\ South Korea \\ ${ }^{4}$ Sher-e-Bangla Agricultural University, Department of Marine Fisheries and Oceanography, Dhaka, Bangladesh
}

\section{Article History}

Received 19 June 2020

Accepted 21 September 2020

First Online 1 October 2020

\section{Corresponding Author \\ Tel.: +8801712384638 \\ E-mail: sakter@du.ac.bd}

\section{Keywords}

Gene expression

Fish

Bioinformatics

$p d c d 4 b$

$\operatorname{miR}-21$

\begin{abstract}
microRNAs (miRNAs) and their target gene expression under oxidative stress play a crucial role in cellular antioxidant regulation. Information on oxidative stress responsive miRNA and their target genes of the fishes of Bangladesh is not reported yet. This study was performed to profile oxidative stress-responsive miRNAs by computational and experimental methods in economically important fish of Bangladesh. Using in silico approach, we could not trace any miRNA of fish of Bangladesh as none has been reported yet in existing databases. We, therefore enlist here the miRNAs that are expressed under different stress conditions in fish applying an extensive literature review. From the list, we selected 10 potential oxidative stressresponsive miRNAs followed by predicting their target genes using miRNA target prediction software (TargetScan Fish). This study decoded the mature sequences of oxidative stress-responsive miRNA (miR-21) in Hilsa (Tenualosa ilisha) and Rohu (Labeo rohita) through specific miRNA primer-based cDNA fragment sequencing. Next, we identified an oxidative stress responsive gene, programmed cell death $4 \mathrm{~b}(p d c d 4 b)$ in hilsa genome and showed that the hilsa miR-21 binds within coding sequence region of the predicted hilsa $p d c d 4 b$. This study is pioneer in decoding oxidative stress responsive miRNA in fish of Bangladesh using an experimental and bioinformatics approach.
\end{abstract}

\section{Introduction}

The fisheries sector is expanding as a potential subsector in the economy of Bangladesh contributing 3.61\% of Gross Domestic Product (GDP) (DoF, 2019). Hilsa (Tenualosa ilisha) is one of the popular sources of nutrition, and export earnings for the country, while rohu (Labeo rohita) is one of the major aquaculture species of Bangladesh. According to the Ministry of Fisheries and Livestock, hilsa contribution to the country's total fish production is about $12 \%$ and around $1 \%$ of the country's GDP (Gross Domestic Product) (DoF, 2019) and rohu is one of the top three aquaculture species of the country (FRSS, 2018). With increasing human interventions of the environment, the water pollution events are increasing day by day that ultimately affects the aquatic ecosystems in Bangladesh (Ekambaram, Narayanan, \& Jayachandran, 2014). The disrupted aquatic environment, in turn, can impose stress to fish and other aquatic organisms that results in a reduction in fish production (Mohanta et al., 2010). Understanding the molecular mechanism of stress tolerance in fish can contribute to stress management in fisheries sector. An imbalance between the environmental stressors induced cellular reactive oxygen species (ROS) level and antioxidant level causes oxidative stress (Lushchak, 2011). Under oxidative stress, ROS can cause potential oxidative damage to 
cellular macromolecules such as lipids, proteins, RNA and DNA (Ekambaram et al., 2014). Recent studies indicate that ROS can interfere with the translational process through the oxidative modification of RNA, rRNA, microRNAs (miRNAs) or mRNA (Kong \& Lin, 2010). MicroRNA (miRNA), a class of highly conserved small non-coding RNA molecules with typically 22 nucleotides can act as post-transcriptional negative controller of gene expression through base-pairing with complementary sequences of mRNA molecules, leads to gene silencing through suppression of translation or mRNA degradation (Wang et al., 2017). miRNA expression can be altered by distinctive stress conditions such as hypoxia or oxidative stress (Magenta et al., 2011a). Oxidative regulation of microRNAs (miRNA) are shown to result in disturbance of the translational process, impairment of protein synthesis and alteration of gene expression that can cause cell deterioration or even cell death (Gupta, 2014). Lau et al. (2014) identified and evaluated the expression profiling of microRNAs in the brain, liver, and gonads of marine medaka (Oryzias melastigma) under hypoxic conditions. Additionally, it was found that hypoxia alters steroidogenesis in female marine medaka through miRNAs regulation (Lai, Li, Tse, Chan, \& Wu, 2016). In response to osmotic stress, miR- 8 was reported to be regulated in zebrafish embryos (Flynt et al., 2009). Moreover, involvement of miRNAs in many biological functions and its regulation in gene expression was studied in various fishes with different stressed conditions, for instance, salt tolerance in tilapia (Yan, Guo, Zhao, \& Zhao, 2012), other osmotic stress in tilapia, freshwater medaka, Japanese eel (W.K.F.Tse, 2014), alkalinity stress and vitamin-E supplement test in Nile tilapia (Zhao, Wu, Wang, \& Zhao, 2016), temperature shock in Atlantic cod (Bizuayehu, Johansen, Puvanendran, Toften, \& Babiak, 2015), and chemical exposure of white fish (Paweł Brzuzan, Woêny, Wolifska, Piasecka, \& Łuczyfski, 2010). A study on common carp recently reported that miR-137-3p, miR-143-3p, miR146a-5p, miR-21-5p, and miR-125b-5p were related to oxidative stress (S. Yang et al., 2019). However, studies especially profiling oxidative stress responsive miRNA and their target genes in case of commercial fish species of Bangladesh are still largely unknown. This study aims to decipher the oxidative stress responsive miRNA in two economically important fishes of Bangladesh, hilsa and rohu. With the avant of the hilsa whole genome sequencing we identified the taget gene of the decoded miRNA.

\section{Materials and Methods}

\section{In Silico Analysis}

The stress-responsive miRNA list was complied through an extensive literature review focusing on miRNA and its regulation in gene expression under different stress conditions. As an initial approach to identify potentially conserved miRNAs in fish of Bangladesh, Mfold 3.1 (http://www.bioinfo.rpi.edu/applications/mfold/), a miRNA prediction software, was explored. From the literature derived stress-responsive miRNA, oxidative stress-responsive miRNAs were selected. These candidate miRNAs were cross-checked and validated by miRNA database, miRBase version 22. Target genes of these candidate miRNAs were predicted through miRNA target prediction software; TargetScan Fish, version 6.2 (Ulitsky et al., 2012) and miRanda (http://www.microma.org) (McWilliam et al., 2013), follwed by cross-check in literature for the confirmation of the prediction. Finally, miRNA-21 was selected for the experimental validation as an oxidative stress resonsive miRNA in this study because miR-21 is conserved in some fishes and already reported as oxidative stress responsive miRNA in studies of human and rat cell lines.

\section{Sample Collection and RNA Isolation}

Hilsa and rohu were selected as experimental organisms based on their economic importance in Bangladesh fisheries sector. Fishes were collected from the Padma river, Bangaldesh and all samples were frozen in liquid nitrogen and stored at $-80^{\circ} \mathrm{C}$ until total RNA isolation. Total RNA was isolated from the fish muscle samples using the Trizol (Invitrogen, USA) reagent according to the manufacturer's protocol (Peterson \& Freeman, 2009). The quality of RNA was checked using $1.5 \%$ agarose gel electrophoresis and with BioPhotometer 6131 (Eppendorf, Germany).

\section{CDNA Synthesis and CDNA PCR}

To get first-strand complementary DNA of total RNA, cDNA was synthesized from total RNA by stemloop reverse transcription PCR (Peterson \& Freeman, 2009). The RNA was initially treated with DNase (Promega) and then reverse-transcribed by using SuperScript III kit (Invitrogen) and a designed stem-loop RT primer for miR-21 (5'-GTCGTATCCAGTGCA GGGTCCGAGGTATTCGCACTGGATACGACGCCAAC-3')

followed by manufacturer's manuals (Peterson \& Freeman, 2009). Then cDNAs were amplified in 30 cycles with DreamTaq DNA Polymerase (Thermo Scientific) using a miR-21 specific PCR primer (5'CGCGCGTAGCTTATCAGACTG-3') and a universal reverse PCR primer (5'-ACCAGTGCAGGGTCCGAGGT-3'). Besides, a house-keeping gene, elfa-1 (Elongation factor alfa 1) as an internal control was amplified by using forward primer (5'-CTTCTCAGGCTGACTGTGC-3') and reverse primer (5'-CCGCTAGCATTACCCTCC-3').

\section{Agarose Gel Electrophoresis and Gel Purification for Sequencing}

Amplified DNA products were visualized by resolving the PCR products in $2 \%$ agarose gel and the 
image was analyzed to compare the desired band size with DNA ladder's band. Amplified DNA products of 75 nt were extracted from the gel and purified using FavorPrepTM gel purification kit (Favogen biotech crop). Purified cDNA PCR product were sequenced (First BASE Laboratories SdnBhd, Malaysia). The sequences were assembled and verified using the BLAST tool against NCBI nucleotide database and miRBase database. NCBI BLAST was performed to check the similarity of sequences with other fishes. The mirRNA sequences were also cheked with miRBase database to find the homologous miRNAs. A multiple sequence alignment was performed using CLC Mainwork bench tool (Quiagen).

\section{Target Gene Detection and Functional Analysis}

Target genes of miR-21 in fish were detected using gene prediction software; TargetScan Fish. From the predicted target genes, programmed cell death $4 \mathrm{~b}$ gene ( $p d c d 4 b)$ sequence of zebrafish (Danio rerio) was retrieved from Ensembl (ENSDARG00000041022). The DNA sequence of 3' untranslated region (3' UTR) of the gene transcript (ENSDART00000182173.1) was used as a queary for the homology search in NCBI blast against Tenualosa hilisa whole genome shotgun contigs (wgs) database. The homolog sequence showing most significant hit scoring max socre 290 , lowest E-value ( $3 e$ ${ }^{75}$ ) and $77 \%$ of identity was retrieved from the GenBank. Hilsa miR-21 was aligned with pdcd4b $3^{\prime}$ UTR of both zebrafish and hilsa to show the binding sites. In another blast search, coding domain sequence (CDS) of pdcd4b of zebrafish was used as query sequence to find homolog sequence in hilsa wgs database. The best hit homolog sequence was used again as query sequence to find homologs in nucleotide collection ( $\mathrm{nr} / \mathrm{nt}$ ) database. This search gives a predicted Clupea harengus pdcd $4 b$ transcript variant sequence $\left(2 \mathrm{e}^{-72}, 89.69 \%\right.$ identity). Using the predicted transcript variant another homology search was performed in two whole genome sequence databases (wgs) of hilsa that gives a predicted transcript homolog of hilsa $p d c d 4 b$. The identified hilsa mir-21 was aligned with the predicted $p d c d 4 b$ transcript of hilsa using CLC Main Workbench (Quiagen) to show the binding site. A multiple sequence alignment was performed using the available fish $p d c d 4 b$ gene and transcript variants from the databases (NCBI, UniprotKB) followed by construction of a phylogenetic tree using Neighbor Joining and Maximum Evolutionary methods in MEGA X platform (Kumar, Stecher, Li, Knyaz, \& Tamura, 2018).

\section{Results}

\section{Stress-Responsive miRNAs in Fish Has Been Enlisted}

We performed an extensive literature search on the miRNA based research on fish. All reported miRNAs expressed under different stressors were retrieved and a stress-responsive miRNA database was created manually. This database includes more than 500 miRNAs which are responsive to thermal stress, cold stress, salinity tolerance, osmotic stress, hypoxia, oxidative stress found in Atlantic salmon, Nile tilapia, Marine medaka, Common carp, Atlantic cod, Zebrafish, Sea cucumber, Silver carp, Whitefish, Shrimps (Supplimentary Table 1). From the manual database, we created a short list of stress responsive miRNAs considering common miRNAs found in two and more studies (Table 1). In the table, we categorized miRNAs into four stress groups (osmotic, thermal, oxidative and hypoxia). Here, osmotic stress includes salt tolerance, alkalinity stress, salinity stress, and osmotic stress. The thermal group includes heat stress, and acute heat stress, temperature effects, cold shock, and acute cold shock. Moreover, oxidative stress group considered hydrogen peroxide stress, cadmium (Cd) induced oxidative stress, saturated fatty acid-induced oxidative stress, vitamin-E diet-induced oxidative stress, microcystin- induced oxidative stress, xenobioticinduced oxidative stress. Hypoxia group also includes aluminium-rich acidic water-induced stress. Table 1 shows that some miRNAs are expressed under specific stress while others are common to different stress, in addition, expression of miRNAs can be up-regulated or down-regulated under the same stress depending on the dosages, exposure times and intensity of the stress. Five miRNA families (miR-21, miR-29, miR-122, miR-135, miR-200) were found to be expressed in all stress groups (osmotic, thermal, oxidative and hypoxia). Besides, Let7a, miR-16a, miR-125b, miR-143, miR-144, miR-155, miR-181a, miR-199, miR-451were found in hypoxia, thermal and oxidative stress. Moreover, miR-15 and miR-153 were commonly expressed under osmotic, thermal and hypoxia stress. Only miR-92a was found in osmotic, thermal and oxidative stress. A noticeable number of miRNAs were shown to be expressed under both hypoxia and thermal stress.

\section{Oxidative Stress-Responsive Candidate miRNAs and Their Target Genes in Fish Were Profiled}

On the basis of the manually constructed list of stress-responsive miRNA in fish, we sorted out the miRNAs which are responsible to oxidative stress. In addition, we searched homologs of fish oxidative stress responsive miRNAs in other animals like human, rat and different cell lines. Finally, we selected 10 conserved miRNAs as potential oxidative stress-responsive miRNAs in fish (Table 2). Using TargetScan Fish software version 6.2 , we have identified putative target genes of these 10 candidate miRNAs from zebrafish genome sequences. For this identification we have considered seed match, context score, and binding capability at 3'-UTR of mRNA. The table also includes functional annotation of the predicted target genes belonging to different gene families. miR-181a-5p and miR-499-5p are related to antioxidant activity and glutathione peroxidase activity. 
Table 1. Compiled stress responsive miRNAs list in fish

\begin{tabular}{|c|c|c|c|}
\hline \multirow[t]{2}{*}{ Stress type } & \multicolumn{2}{|c|}{ Expressed miRNAs } & \multirow[t]{2}{*}{ References } \\
\hline & Up-regulation & Down-regulation & \\
\hline Osmotic & $\begin{array}{l}\text { miR-429a, miR-429b, miR-200a, miR-200b, } \\
\text { miR-200c, miR-135b, miR-2011 }\end{array}$ & $\begin{array}{l}\text { miR-429, miR-200a, miR-21, miR-30c, } \\
\text { miR-10, miR-10a, miR-122, miR-190a, } \\
\text { miR-153-3p, miR-2008, miR-29b, miR- } \\
\text { 92a, miR-2013, miR-124, miR-15 }\end{array}$ & $\begin{array}{l}\text { (Flynt et al., 2009; Goodale et al., } \\
\text { 2019; Tian, Shang, Guo, Chang, \& } \\
\text { Jiang, 2019; Yan, Guo, et al., 2012; } \\
\text { Yan, Zhao, et al., 2012; Zhao et al., } \\
\text { 2016) }\end{array}$ \\
\hline Thermal & $\begin{array}{l}\text { miR-451, miR-200b, miR-21, miR-30d, miR- } \\
\text { 30e, miR-135c, miR-10b, miR-10c, miR-10d, } \\
\text { miR-122, miR-29b-1, miR-92a, miR-124, } \\
\text { miR-146a, miR-146d, miR-22a, miR-22b, let- } \\
\text { 7a, let-7b, let-7d, let-7f, let-7j, let-7h, miR- } \\
\text { 203a, miR-203b, miR-1, miR-16a, miR-16c, } \\
\text { miR-128, miR-27a, miR-27d, miR-27e, miR- } \\
\text { 17, miR-489, miR-133, miR-499, miR-730, } \\
\text { miR-144, miR-7132a, miR-7132b, miR-181a, } \\
\text { miR-181b, miR-338, miR-301c, miR-7, miR- } \\
\text { 125b, miR-199, miR-194, miR-99, miR-103, } \\
\text { miR-192, miR-206, miR-24, miR-23, miR- } \\
\text { 2184, miR-204, miR-2188, miR-143, miR- } \\
\text { 106, miR-130b }\end{array}$ & $\begin{array}{l}\text { miR-200a, miR-30a, miR-30b, miR-30c, } \\
\text { miR-30d, miR-10c, miR-10d, miR-122, } \\
\text { miR-153a-3p, miR-92b, miR-92a, miR- } \\
\text { 124, miR-146a, miR-22a, let-7a, let-7b, } \\
\text { let-7d, let-7g, let-7j, let-7h, miR-26a, } \\
\text { miR-203a, miR-203b, miR-1, miR-16b, } \\
\text { miR-27c, miR-17, miR-489, miR-133, } \\
\text { miR-202, miR-462, miR-7132a, miR- } \\
\text { 7132b, miR-19a, miR-19b, miR-19c, } \\
\text { miR-181a, miR-181b, miR-338, miR- } \\
\text { 301a, miR-301b, miR-301c, miR-458-3p, } \\
\text { miR-7, miR-125b, miR-199, miR-142, } \\
\text { miR-155, miR-18, miR-15, miR-103, } \\
\text { miR-192, miR-34c, miR-206, miR-145, } \\
\text { miR-8, miR-363, miR-210, miR-20, miR- } \\
\text { 130b, miR-130c, miR-216a, miR-29a, } \\
\text { miR-139 }\end{array}$ & $\begin{array}{l}\text { (Bao et al., 2018; Bizuayehu et al., } \\
\text { 2015a; Hung et al., 2016; Li and Xu, } \\
\text { 2018; F. Ma et al., 2019; Qiang et } \\
\text { al., 2017a; Qiang et al., 2018; Sun et } \\
\text { al., 2019a, 2019b; Vasadia et al., } \\
\text { 2019; Yang et al., 2011; Zheng et al., } \\
\text { 2018; Zhou et al., 2019) }\end{array}$ \\
\hline Oxidative & $\begin{array}{l}\text { miR-451, miR-200c, miR-21, miR-135b, miR- } \\
\text { 122, miR-29a, miR-92a, miR-146a, let-7c, } \\
\text { miR-16, miR-16a, miR-181a, miR-125b, miR- } \\
\text { 199, miR-155, miR-34a, miR-143, miR-223, } \\
\text { miR-9 }\end{array}$ & $\begin{array}{l}\text { miR-451, miR-21, miR-122, miR-146a, } \\
\text { let-7a, miR-16, miR-144, miR-19a, miR- } \\
\text { 125b, miR-143, miR-223 }\end{array}$ & $\begin{array}{l}\text { (Pawe Brzuzan, Wony, Woliska, \& K. } \\
\text { uczyski, 2013; Burgos-Aceves, } \\
\text { Cohen, Smith, \& Faggio, 2018; Chen } \\
\text { et al., 2015; J. Ma, Chen, Xin, \& Li, } \\
\text { 2019; Qiang, Bao, et al., 2017; } \\
\text { Qiang et al., 2019; Qiang, Tao, He, } \\
\text { Sun, \& Xu, 2017; Tang et al., 2013; } \\
\text { S. Yang et al., 2019; Yu et al., 2010; } \\
\text { Q. Zhang et al., 2019) }\end{array}$ \\
\hline Hypoxia & $\begin{array}{l}\text { miR-451, miR-200b, miR-135a, miR-153-3p, } \\
\text { miR-2008, miR-29b-3p, let-7e, let-7b, let-7g, } \\
\text { let-7h, miR-203a, miR-203b, miR-1-3p, miR- } \\
\text { 16a, miR-27b, miR-489, miR-133, miR-202, } \\
\text { miR-499, miR-144-5p, miR-338, miR-199, } \\
\text { miR-194, miR-15, miR-103, miR-192, miR- } \\
\text { 206, miR-23, miR-145, miR-363, miR-143, } \\
\text { miR-204, miR-216a, miR-210, miR-184, miR- } \\
2188\end{array}$ & $\begin{array}{l}\text { miR-200, miR-21, miR-122, miR-190a, } \\
\text { miR-2011, miR-2008-5p, miR-2013-3p, } \\
\text { let-7a, let-7d, miR-27a, miR-17, miR- } \\
\text { 489, miR-133, miR-181b, miR-338, miR- } \\
\text { 301a, miR-301c, miR-125b, miR-142, } \\
\text { miR-155, miR-99, miR-103, miR-2184, } \\
\text { miR-9, miR-204, miR-216b, miR-20, } \\
\text { miR-31, miR-130a }\end{array}$ & $\begin{array}{l}\text { (Huang et al., 2017; Huo et al., } \\
\text { 2017; Kure et al., 2013; Lau et al., } \\
\text { 2014; A. C.-K. Tse, Li, Chan, Wu, \& } \\
\text { Lai, 2015; G. Zhang et al., 2016; } \\
\text { Zhao, Zhu, Yan, Zhao, \& Wang, } \\
\text { 2014) }\end{array}$ \\
\hline
\end{tabular}

miR-200c-5p, miR-200a-5p and miR-141-5p are involved in antioxidant and catalase activity. In addition, heat shock protein binding is strongly regulated through let7f, miR-21, and miR-143 expression. On the other hand, miR-21, miR-155, and miR-499-5p are shown to regulate programmed cell death, to suppress proliferation, tumor and cell cycle progression and to induce apoptosis.

\section{Mature miR-21 Sequenecs in Hilsa and Rohu Were Decoded}

From the enlisted oxidative stress responsive miRNAs, miR-21 was selected for the experimental study because of its known oxidative stress response in human and other animals (Table 2). This study confirmed the presence of miR-21 in rohu and hilsa using miR-21 specific CDNA PCR (Figure 1). For this specific PCR, we designed degenerate stem-loop reverse transcription primer and miR-21 specific PCR primers. The mature miR-21 was sequenced (Table 3) and performed homology search using blast against miRBase and $\mathrm{NCBI}$ database for the confirmation. Finally, we reported the mature miR-21 sequences in the rohu and hilsa samples. The sequence length in hilsa and rohu was 22 and 16 nucleotides (nt) respectively. The study identified full sequence of mature miR-21 only in hilsa and partial sequence of rohu miR-21. From the sequences we found $5 \mathrm{nt}$ similarities between hilsa and rohu at $5^{\prime}$ end. Multiple alignment with other fish miRNAs of miR-21 family from the miRBase showed that identified miRNAs are highly similar with other members of the miR-21 family (Figure 2). Mature miR-21 of hilsa, however, showed divergence at $3^{\prime}$ region while compared with miR-21 family.

\section{Hilsa miR-21 Binds with Predicted Hilsa Programmed Cell Death 4b (pdcd4b)}

Programmed cell death $4 \mathrm{~b}(p d c d 4 b)$ is a known target gene for miR-21 reported in zebrafish (Wei et al., 2014). We identified the putative hilsa $p d c d 4 b$ to show 
Table 2. Potential oxidative stress-responsive miRNAs in fish and their target genes with functions. Functional analysis via Gene Ontology, UniProt and GeneCards (Ashburner et al., 2000; Safran et al., 2010; "UniProt: a hub for protein information," 2015)

\begin{tabular}{|c|c|c|c|}
\hline miRNAs name and sequence & $\begin{array}{l}\text { Target } \\
\text { genes* }\end{array}$ & Genes Functions & $\begin{array}{l}\text { Homolog found in other } \\
\text { animals }\end{array}$ \\
\hline $\begin{array}{l}>\text { dre-miR-181a-5p } \\
\text { AACAUUCAACGCUGUCGGUGAGU }\end{array}$ & $\begin{array}{c}\text { Gpx8, } \\
\text { Cat }\end{array}$ & $\begin{array}{c}\text { Antioxidant, Glutathione } \\
\text { peroxidase activity, response } \\
\text { to oxidative stress }\end{array}$ & $\begin{array}{c}\text { Human umbilical vein } \\
\text { endothelial cells (G. Liu, Li, \& } \\
\text { Gao, 2016), embryonic } \\
\text { cardiomyocyte cell line H9C2 } \\
\text { (L. Wang et al., 2014) }\end{array}$ \\
\hline $\begin{array}{l}>\text { dre-miR-200c-5p } \\
\text { CAUCUUACAAGGCAGUUUUGGA }\end{array}$ & Cat & $\begin{array}{l}\text { Anti oxidant, Catalase activity, } \\
\text { oxidoreductase activity, } \\
\text { response to oxidative stress, } \\
\text { hydrogen peroxide catabolic }\end{array}$ & $\begin{array}{l}\text { human umbilical vein } \\
\text { endothelial cells (Morii et } \\
\text { al., 2019), epileptic rat } \\
\text { (Du, Chi, \& An, 2019) }\end{array}$ \\
\hline >dre-let-7f UGAGGUAGUAGAUUGUAUAGUU & hspb6 & $\begin{array}{l}\text { Heat shock protein, Specific } \\
\text { function in vasodilation, } \\
\text { platelet function, and insulin } \\
\text { resistance and in smooth and } \\
\text { cardiac muscle }\end{array}$ & $\begin{array}{l}\text { Human cardiac cell line } \\
\text { (Qiang et al., 2018), Human } \\
\text { umbilical vein endothelial } \\
\text { cells (Dhahri et al., 2017) }\end{array}$ \\
\hline $\begin{array}{l}>\text { dre-miR-21 } \\
\text { UAGCUUAUCAGACUGGUGUUGGC }\end{array}$ & $\begin{array}{l}p d c d 4 b \\
h s p b 8\end{array}$ & $\begin{array}{c}\text { Programmed cell death 4b, } \\
\text { Biological Process, } \\
\text { atrioventricular valve } \\
\text { development, heat shock } \\
\text { protein b8 }\end{array}$ & $\begin{array}{l}\text { Cardiomyocytes cell line } \\
\text { (Wei, Li, Kim, Sun, \& Gupta, } \\
\text { 2014), Patients with Gastric } \\
\text { Cancer (Tu et al., 2014) }\end{array}$ \\
\hline $\begin{array}{l}>\text { dre-miR-499-5p } \\
\text { UUAAGACUUGCAGUGAUGUUUA }\end{array}$ & $\begin{array}{l}\text { GPX8, } \\
\text { pdcd4 }\end{array}$ & $\begin{array}{l}\text { Glutathione peroxidase } \\
\text { activity, response to oxidative } \\
\text { stress. } p d c d 4 \text { suppresses } \\
\text { proliferation, tumor and cell } \\
\text { cycle progression and induces } \\
\text { apoptosis. }\end{array}$ & $\begin{array}{l}\text { Human colorectal cancer cell } \\
\text { line (X. Liu et al., 2011) }\end{array}$ \\
\hline >dre-miR-143 UGAGAUGAAGCACUGUAGCUC & $\begin{array}{l}\text { pdcd8, } \\
\text { hspa8, } \\
\text { hspe1, } \\
\text { GPX2 }\end{array}$ & $\begin{array}{l}\text { Apoptosis-inducing factor, } \\
\text { Heat shock protein binding, } \\
\text { ATPase activity, heat shock } 10 \\
\text { protein } 1 \text { has a response to } \\
\text { unfolded protein, glutathione } \\
\text { peroxidase } 2 \text { has a response to } \\
\text { reactive oxygen species }\end{array}$ & $\begin{array}{l}\text { Rats and human hepatic cell } \\
\text { line (Wan et al., 2016) }\end{array}$ \\
\hline >dre-miR-155 UUAAUGCUAAUCGUGAUAGGGG & $p d c d 2$ & $\begin{array}{l}\text { Programmed cell death } 2 \text { has } \\
\text { metal ion binding properties, } \\
\text { involved in the regulation of } \\
\text { mitotic nuclear division }\end{array}$ & $\begin{array}{l}\text { Rats and human hepatic cell } \\
\quad \text { line (Wan et al., 2016) }\end{array}$ \\
\hline >dre-miR-451 AAACCGUUACCAUUACUGAGUU & $p d c d 4 b$ & $\begin{array}{c}\text { Programmed cell death } 4 \mathrm{~b} \text { has } \\
\text { role in atrioventricular valve } \\
\text { development }\end{array}$ & $\begin{array}{l}\text { Mice erythroid cells (W. } \\
\text { Wang et al., 2017) }\end{array}$ \\
\hline $\begin{array}{l}\text { >dre-miR-200a-5p } \\
\text { CAUCUUACCGGACAGUGCUGGA }\end{array}$ & Cat & $\begin{array}{l}\text { Catalase activity, } \\
\text { oxidoreductase activity, } \\
\text { response to oxidative stress, } \\
\text { hydrogen peroxide catabolic } \\
\text { process }\end{array}$ & $\begin{array}{l}\text { Chicken cardiac tissue (T. } \\
\text { Yang et al., 2018) }\end{array}$ \\
\hline $\begin{array}{l}>\text { dre-miR-141-5p } \\
\text { CAUCUUACCUGACAGUGCUUGG }\end{array}$ & Cat & $\begin{array}{c}\text { Catalase activity, } \\
\text { oxidoreductase activity, } \\
\text { response to oxidative stress, } \\
\text { hydrogen peroxide catabolic } \\
\text { process }\end{array}$ & $\begin{array}{l}\text { Placentae of patients with } \\
\text { preeclampsia (Y. Wang et al., } \\
\text { 2019) }\end{array}$ \\
\hline
\end{tabular}

* Gpx8, Gpx2 (Glutathione peroxidase 8 and 2 gene); Cat (Catalase gene); $h s p b 6, h s p b 8, h s p a 8$, hspe1 (heat shock protein b6, $\mathrm{b} 8, \mathrm{a} 8$ and $\mathrm{e} 1$ gene); $p d c d 2, p d c d 4 b$ (Programmed cell death 2 and $4 \mathrm{~b}$ gene)

the hilsa miR-21 could bind the target gene. In Zebrafish miR-21 binds to 3' UTR of pdcd4b (Wei et al., 2014), therefore we searched whether hilsa miR-21 could bind to its target hilsa $p d c d 4 b$ gene. For this purpose we first annotate the $3^{\prime}$ UTR of hilsa $p d c d 4 b$ from hilsa whole genome sequence using homology search. After pairwise alignment, we found that the hilsa miR-21 does not bind to $3^{\prime}$ UTR of hilsa $p d c d 4 b$. Next, we predicted the gene sequence of hilsa $p d c d 4 b$ and interestingly we observed a 9 nucleotides match with the coding region of predicted $p d c d 4 b$ (Figure 3 ). Although, hilsa miR-21 does not have bindins site in $3^{\prime}$ UTR of hilsa $p d c d 4 b$, 
(A)

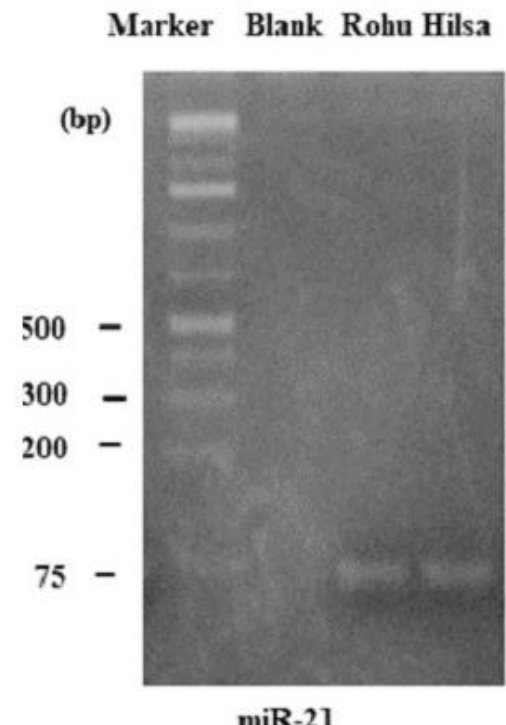

(B)

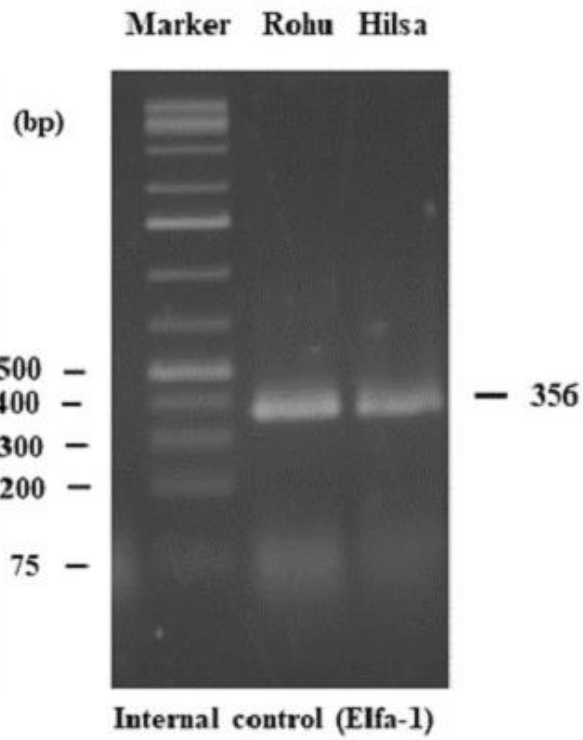

Figure 1. Validation of PCR amplified miR-21 cDNA fragments resolved on agarose gel. (A) cDNA fragments of miR-21 from Rohu and Hilsa, (B) Amplified cDNA fragment of elongation factor (Efla-1) from Rohu and Hilsa. Efla-1 was used as an internal control for the RT PCR

Table 3. Identified miR-21 sequence in Hilsa (Tenualosa ilisha) and Rohu (Labeo rohita) fish

\begin{tabular}{lc}
\hline Species & miR-21 Sequence (5'-3') \\
\hline Hilsa (Tenualosa ilisha) & UAGCUAUCAGACUGGUGUGCGU \\
Rohu (Labeo rohita) & UAGCUUAUCAGACAGG \\
\hline
\end{tabular}

however it binds with 3' UTR of zebrafish $p d c d 4 b$ (Figure 3). Important to note that the predicted hilsa $p d c d 4 b$ showed close homology with Clupea harengus belonging to the same taxonomic group (Clupeidae) (Figure 4A) but phylogenetically diverged from zebrafish pdcd4b (Figure 4B).

\section{Discussion}

Fish could be stressed due to different factors such as temperature variation, hypoxia, salinity, osmotic imbalance, heavy metals, diseases and so on (Topal et al., 2017). Among the various regulatory mechanisms in a biological process, regulation of gene expression by microRNAs (miRNAs) is of critical importance. Different stress conditions can up-regulate the level of miRNAs synthesis that down-regulate gene expression through the activities of miRNA-protein complexes and viceversa. Single miRNA mutant was shown to display phenotypic crisis in stress conditions (Van Rooij et al., 2007). Definite roles of some miRNAs expressed in zebrafish, medaka, Atlantic salmon, rainbow trout, Nile tilapia have been discussed. So far, there is no miRNA research in the context of fisheries sector of Bangladesh.
Therefore, this pioneer study on stress responsive miRNA in the important fish species of Bangladesh was performed to explore the presence of such miRNAs and to contribute in better understanding the role of miRNA on fish biology.

We created a list of stress responsive miRNAs in fish reported from available published works (Supplementary Table 1). The list included more than 500 miRNAs expressed in different stress conditions. Regarding the published literature, we found some stressors that can regulate miRNAs and gene expressions like osmotic imbalance, alkalinity changes, salinity variation, cold shock, heat shock, temperature variations, metal, chemical and diet-induced oxidative stress, hypoxia. Then, we categorize the miRNAs list considering four basic types of stresses such as osmotic, thermal, hypoxia and oxidative stress. From the list, it is noticed that few miRNAs are related to all stresses, some are related to two or more stresses and some miRNAs are shown to be expressed in certain stress only. It is reported that the functions or expression of miRNAs during stress can be controlled by four factors-miRNAs level, mRNA targets level, the activity or the mode of action of miRNA-protein complexes; and the changes or 


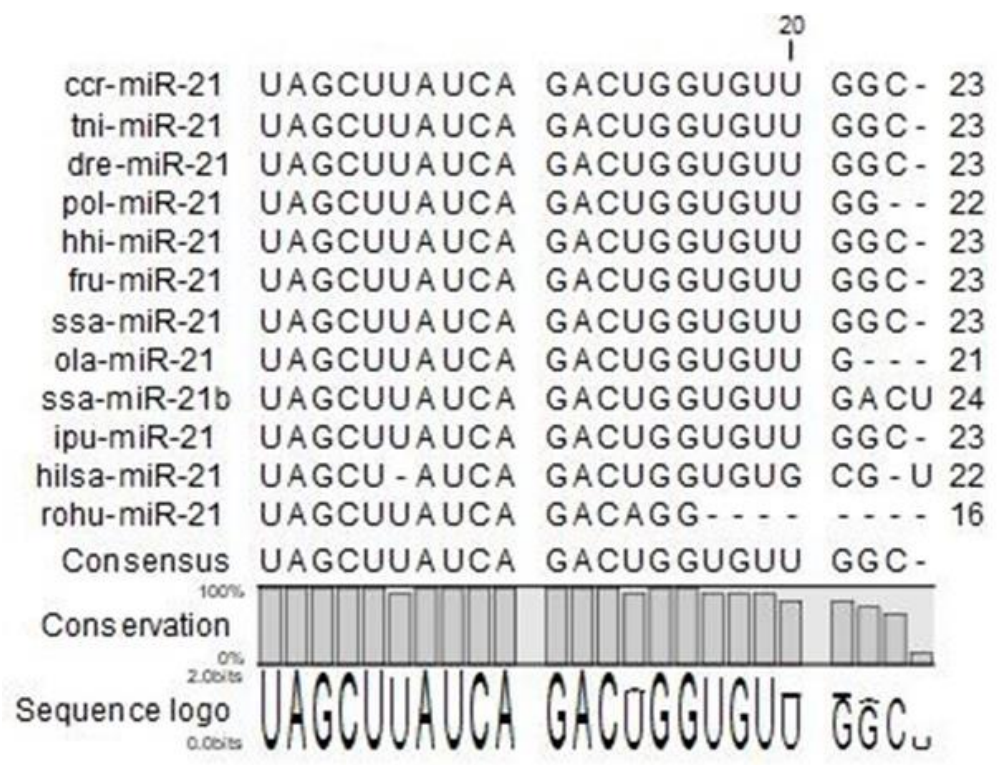

Figure 2. Multiple alignments of identified two miRNAs (hilsa and rohu miRNA) with other miRNAs of miR-21 family. (ola= Oryzias latipes, $\mathrm{ssa}=$ Salmo salar, $\mathrm{ccr}=$ Cyprinus carpio, $\mathrm{tni}=$ Tetraodon nigroviridis, hhi= Hippoglossus hippoglossus, fru= Fugu rubripes, dre= Danio rerio, ipu= Ictalurus punctatus, pol= Paralichthys olivaceus, rohu= Labeo rohita, hilsa=Tenualosa ilisha).

(A) Zebrafish pdcd4b 3'UTR GAACAUUUUUAUUUUUAUAUUUCGgUAGACUGGUGGaUgUGagaUGUGCCGgACUUACCUGCU

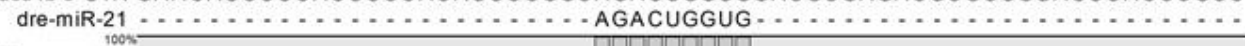
Conservation

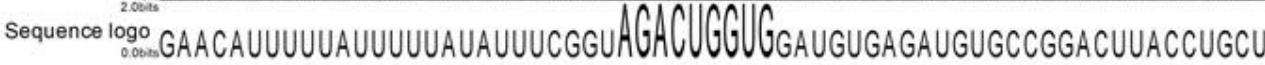

(B) Zebrafish pdcd4b AAGgGUCCAGAACAUUUUUAUUUUUAUAUUUCGGUAGACUGGUGGAUGUGAGAUGUGCCG

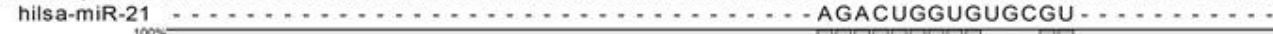
Conservation

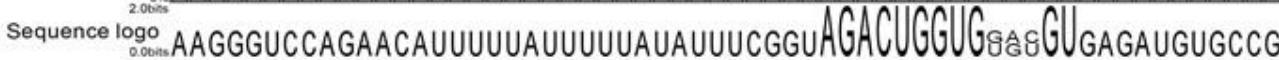

(C) Hilsa pdcd4b 3'UTR UAUCUAUCUAUCUAUCUAUCUAUCUAUCUAUCCAUCCAUCCAUCCAUCCAUCUAUCUAUC

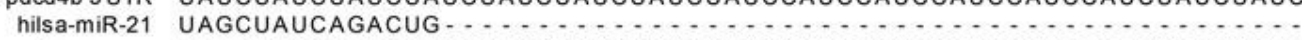
Consensus UA* CUAUC $\cdots$ CU* UCUAUCUAUCUAUCUAUCCAUCCAUCCAUCCAUCCAUCUAUCUAUC Conservation sequence logo ${ }_{0.000}^{2000}$

(D) Predicted Hilsa pded4b AGgGaAgGguCUUAGUCCACAGAUCACACCAUCAGACUGCAUACAAGgACUUUACUAC

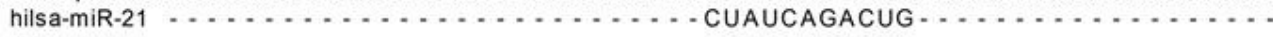
Consensus AGGGAAGGGUCUUAGUCCACAGAUCACAC*AUCAGACUGCAUACAAGGACUUUACUAC

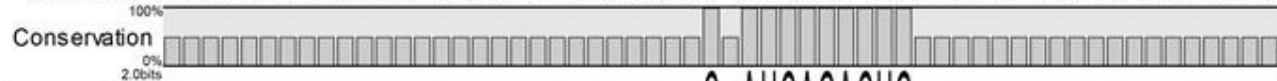

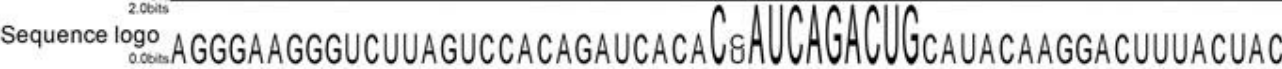

Figure 3. Binding site of miR-21. (A) dre-miR-21 targets $3^{\prime}$ untranslated region (UTR) of $p d c d 4 b$ gene of Danio rerio, (B) identified hilsa (Tenualosa ilisaha) miR-21 binds to $3^{\prime}$ UTR of pdcd4b gene of Danio rerio, (C) improper binding of identified hilsa miR-21 at $3^{\prime}$ UTR of the predicted hilsa pdcd4b, (D) a 9 mer binding of hilsa miR-21 at the coding domain sequence (CDS) of predicted hilsa $p d c d 4 b$ gene.

modifications of these factors are reported to be modulated by many signalling pathways (Leung \& Sharp, 2010). The literature revealed that certain stresses could induce specific miRNAs, which can up-regulate or downregulate specific target genes, thus can play crucial roles in different biological and cellular processes. For instance, miR-429 was found as crucial regulator in osmotic stress by targeting osmotic stress transcription factor 1 (OSTF1) in tilapia and miR-429 silencing can affect osmoregulation in tilapia (Yan, Zhao, Guo, \& Zhao, 2012). Another study showed that a hypoxia responsible miRNA, let-7b acts downstream of hypoxia-inducible 
(A)

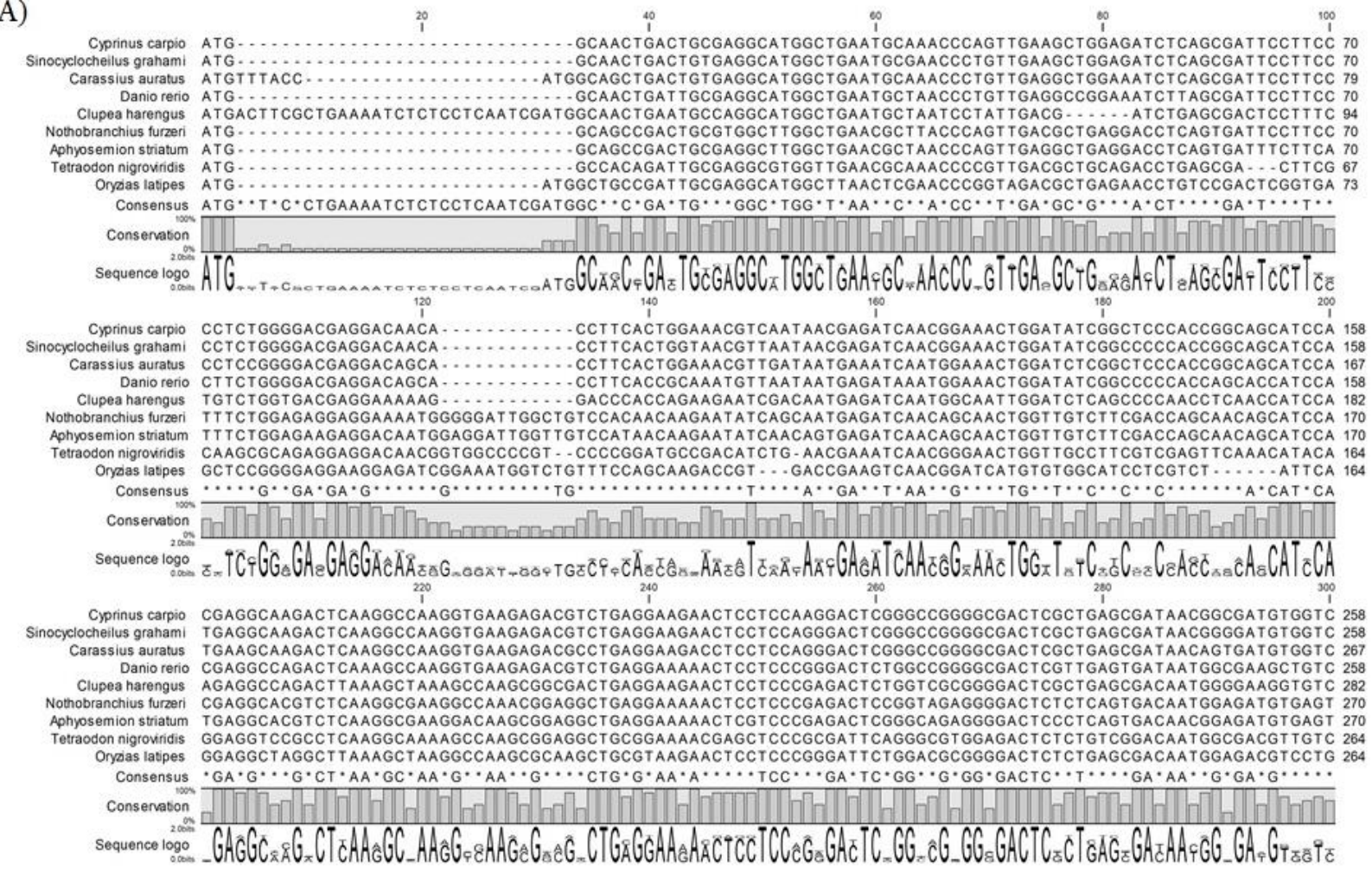

(B)

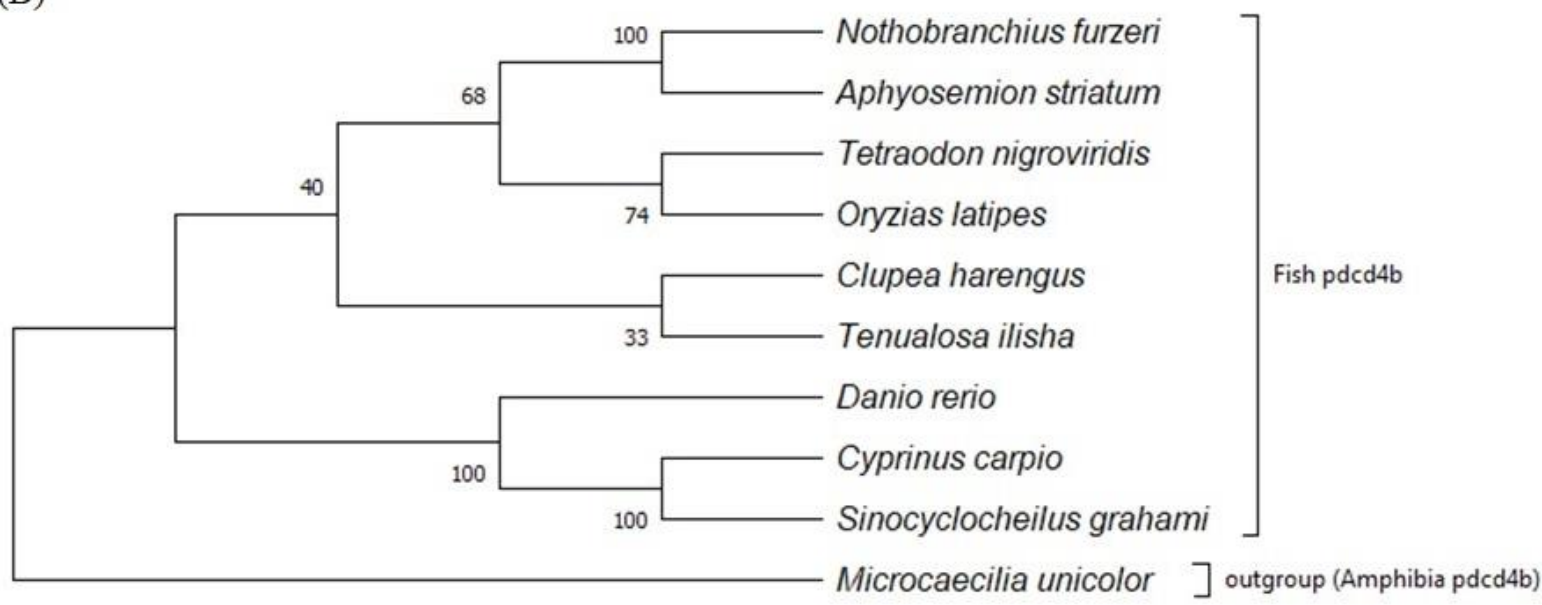

Figure 4. Fish $p d c d 4 b$ gene divergence. (A) Multiple sequence alignment of available fish $p d c d 4 b$ gene sequences. The number on top represents alignment position whereas the numbers on the right hand side represent the individual fish $p d c d 4 b$ gene sequence position. The ash bargraphs shows the conservance of residues among the sequences. (B) Phylogenetic tree construction using $p d c d 4 b$ genes among fish. The evolutionary history was inferred using the Neighbor-Joining method (Saitou and Nei, 1987). The optimal tree with the sum of branch length $=2.07929047$ is shown. The percentage of replicate trees in which the associated taxa clustered together in the bootstrap test (1000 replicates) are shown next to the branches (Felsenstein, 1985). The evolutionary distances were computed using the Maximum Composite Likelihood method (Tamura et al., 2004) and are in the units of the number of base substitutions per site. This analysis involved 10 nucleotide sequences. Codon positions included were $1 s t+2 n d+3 r d+$ Noncoding. All ambiguous positions were removed for each sequence pair (pairwise deletion option). There were a total of 1471 positions in the final dataset. Evolutionary analyses were performed in MEGA X (Kumar et al., 2018).

factor-1 $\alpha$ to assist in hypoxia-mediated cell proliferation and cell cycle regulation in zebrafish (Huang et al., 2017). Moreover, it was revealed that miR-489-3p regulates the oxidative stress response in the liver and gill tissues of hybrid yellow catfish by targeting $\mathrm{Cu} / \mathrm{Zn}-\mathrm{SOD}$ (Copper/zinc superoxide dismutase) which has critical roles in protecting cells and tissues against oxidative damage (Qiang et al., 2019). Recently, several studies showed an in silico approach to identify conserve miRNAs in various species using an available database like EST, GSS, protein, and mRNA databases (Hairulislam, Saravanan, Sekar, \& Karikalan, 2014; X. H. Li, Wu, Tang, \& Hu, 2015; Xu et al., 2013). This study tried to explore such types of data for the fish species ( $T$. ilisha 
and L. rohita) of Bangladesh in $\mathrm{NCBI}$ and miRBase through in silico approach. As there are no available GSS and EST sequences of such fish species of Bangladesh, the study could not identify conserved miRNAs in Bangladeshi fishes through in silico approach.

This study selected 10 potential oxidative stress responsive miRNAs in fish through screening the stress related miRNAs list. We also confirmed the putative target genes of these miRNAs from zebrafish genome sequences through TargetScan Fish software. The identified miRNAs were highly conserved and predicted target genes were found to be involved in various biological processes such as apoptosis, programmed cell death, cell development, antioxidant activities, stress biology, etc. summarized in Table 2 (Ashburner et al., 2000; Safran et al., 2010; "UniProt: a hub for protein information," 2015). Among them, miR-181a and miR499-5p can directly inhibit glutathione peroxidase activity, oxidoreductase, and peroxidase activity by targeting $g p x 8$ (Glutathione Peroxidase 8 ) in response to oxidative stress. miR-499-5p also involves in programmed death cell and suppressing tumor proliferation. Catalase gene (Cat) that involves in antioxidant activity, peroxisomal, catabolic pathway, free radical detoxification, peroxidase and catalase activity, is regulated by miR-141-5p, miR-200a-5p, miR200c-5p and miR-181a. Heat shock protein binding $(h s p b)$ gene family that works on heat shock protein binding, identical protein binding and protein homodimerization activity, is regulated by the expression of miR-143, miR-155, miR-451, let-7h. The miR-let-7 family, key regulators during tumorigenesis, can be down regulated by ROS in a p53 (tumor protein gene)-dependent mechanism during oxidative stress in a cancer cell line (Saleh et al., 2011). There are several studies about alterations in miRNAs expression by oxidative stress. For example, miR-451 regulates the expression of antioxidant enzyme genes Cat and Gpx1 to protect erythrocytes cells of mammals and fish against ROS. An oxidative stress induced down-regulation of miR- 451 may impair the deleterious effects of oxidative stress on erythroid cells triggering severe anemia in fish (Yu et al., 2010). A study on juveniles of O. niloticus showed that vitamin-E deficiency causes downregulation of miR-223, miR-146a, miR-16, miR-122, and suppression of $S O D$ activity in liver. But with excessive supplementation of vitamin E, hepatic SOD (Superoxide Dismutase) and CAT was still suppressed, with an upregulation of miR-21, miR-223, miR-146a, miR-125b, miR-181a, miR-16, miR-155 and miR-122a (Tang et al., 2013). It has been also reported that miR-21 and mR-223 may suppress the expression of gpx5 gene, and their upregulation may contribute to oxidative stress. miR-200c found to be upregulated with a down-modulation of its target protein ZEB1 (Zinc Finger E-Box Binding Homeobox 1) by oxidative stress and induces endothelial cell apoptosis and senescence via ZEB1 inhibition (Magenta et al., 2011b).
In this study, we selected miR-21 to identify in hilsa and rohu because miR-21 is known stress-responsive miRNA and it showed the regulatory behavior in many organisms (Cheng et al., 2009; Kolpa et al., 2013; Tang et al., 2013). For example, miR-21 acts as a proproliferative and anti-apoptotic factor in the context of kidney regeneration in fish that specifies the role of miR21 in the kidney. Another study found that miR-21 is down regulated upon alkalinity stress in Nile tilapia and directly regulates VEGFC (Vascular Endothelial Growth Factor C) gene expression by targeting the $3^{\prime}$ untranslated regions (UTRs) of their mRNAs, and inhibition of miR-21 significantly increases the levels of VEGFC expression in vivo. Thus, miR-21 knockdown plays a protective role in alkalinity tolerance in tilapia (Zhao et al., 2016). We identified the mature miR-21 sequence of hilsa and rohu fish of Bangladesh. Multiple sequence alignment with miR-21 family of mircoRNA reveals that except $3^{\prime}$ region of hilsa miR-21, the mature sequence is conserved with other fish species. The divergence at $3^{\prime}$ region of mature hilsa miR-21 provoked to validate the identified sequence. Therefore, programme cell death $4 b(p d c d 4 b)$, a reported target gene of zebrafish miR-21 was retrieved from Ensemble database to perform a homology search in hilsa whole genome database (Das et al., 2018). Based on the homology search the putative hilsa $p d c d 4 b$ sequence was identified and aligned with the identified hilsa miR21 sequence to find its potential binding site. Unlike zebrafish miR-21, the mature hilsa miR-21 binds to the putative coding domain sequences (CDS) of $p d c d 4 b$ gene, revealing that hilsa miR-21 and $p d c d 4 b$ expression might be negatively correlated. Differences in binding sites between zebrafish and hilsa $p d c d 4 b$ could be explained by the fact that the pair wise alignment of zebrafish $p d c d 4 b$ and predicted hilsa $p d c d 4 b$ showed quite divergent sequences. In addition, zebrafish and hilsa belongs to two different taxonomic group, Cyprinidae and Clupeidae family respectively. However, the predicted hilsa $p d c d 4 b$ shows close homology with the predicted Clupea harengus pdcd4b transcript variant. Indeed, both Tenualosa and Clupea harengus belongs to same taxonomic group (Clupeidae). The phylogenetic analysis with the $p d c d 4 b$ gene among fish species using both Neighbor Joining and Maximum Evolutionary method revealed similar tree topology. Zebrafish $p d c d 4 b$ diverged quite earlier than the hilsa $p d c d 4 b$ gene. There are studies showing that microRNAs usually bind to 3' UTR as well as could bind to the coding regions of the genes (Forman, Legesse-Miller, \& Coller, 2008; Schnall-Levin, Zhao, Perrimon, \& Berger, 2010). Growing evidence suggests that oxidative stress upregulates programmed cell death gene ( $p d c d)$ expression in patients with gastric cancer via miR-21 down regulation (Tu et al., 2014). It is reported that miR21 is overexpressed in solid tumors of the lung, breast, stomach, prostate, colon, brain, head and neck, esophagus and pancreas encouraging cell transformation and acts as an oncogene by a 
mechanism that involves in translational repression of the tumor suppressor gene ( $p d c d 4)$ (Lu et al., 2008). miRNAs (miR-21-5p, miR-223-3p, and miR-223-5p) in fish associated with biotic stress have been identified and it would be a novel biomarker to manage biotic stress in fish (Hairul-islam et al., 2014).

\section{Conclusion}

The molecular understanding of oxidative stress in fish has great significance for environmental and aquatic toxicological studies. This study pioneers in decoding oxidative stress responsive miRNA in fish of Bangladesh and in utilizing experimental and bioinformatics approaches to predict target gene. Proper identification of stress-responsive miRNA could potentially contribute in developing biomarker and to develop stress tolerant fish thus handling the raising concern about aquatic pollution in fisheries sector of Bangladesh. Future perspectives of this study are to focus on functions, stress dose-responses and temporal expressions of the identified miRNAs and their target genes.

\section{Acknowledgements:}

Ministry of Science and Technology, Bangladesh Govt. funded this study.

\section{References}

Alvarez-Garcia, I., \& Miska, E.A. (2005). MicroRNA functions in animal development and human disease. Development, 132(21).

Ashburner, M., Ball, C.A., Blake, J.A., Botstein, D., Butler, H., Cherry, J.M., ... Sherlock, G. (2000, May). Gene ontology: Tool for the unification of biology. Nature Genetics. https://doi.org/10.1038/75556

Bao, J.W., Qiang, J., Tao, Y.F., Li, H.X., He, J., Xu, P., \& Chen, D.J. (2018). Responses of blood biochemistry, fatty acid composition and expression of microRNAs to heat stress in genetically improved farmed tilapia (Oreochromis niloticus). Journal of Thermal Biology, 73, 91-97. https://doi.org/10.1016/j.jtherbio.2018.02.007

Bartel, D.P. (2009, January). MicroRNAs: Target Recognition and Regulatory Functions. Cell. https://doi.org/10.1016/j.cell.2009.01.002

Bizuayehu, T.T., Johansen, S.D., Puvanendran, V., Toften, H., \& Babiak, I. (2015). Temperature during early development has long-term effects on microRNA expression in Atlantic cod. BMC Genomics, 16(1), 305. https://doi.org/10.1186/s12864-015-1503-7

Brzuzan, Pawe, Wony, M., Woliska, L., \& K. uczyski, M. (2013). Discovering the Role of MicroRNAs in MicrocystinInduced Toxicity in Fish. In an Integrated View of the Molecular Recognition and Toxinology - From Analytical Procedures to Biomedical Applications. InTech. https://doi.org/10.5772/52204

Brzuzan, Paweł, Woêny, M., Wolifska, L., Piasecka, A., \& Łuczyfski, M.K. (2010). MicroRNA expression in liver of whitefish (Coregonus lavaretus) exposed to microcystinLR, 6(2), 53-60.
Burgos-Aceves, M.A., Cohen, A., Smith, Y., \& Faggio, C. (2018). MicroRNAs and their role on fish oxidative stress during xenobiotic environmental exposures. Ecotoxicology and Environmental Safety, 148(December 2017), 995-1000. https://doi.org/10.1016/j.ecoenv.2017.12.001

Cadet, J., Douki, T., Gasparutto, D., \& Ravanat, J.-L. (2003). Oxidative damage to DNA: Formation, measurement and biochemical features. Mutation research (Vol. 531).

Cao, X., Yeo, G., R Muotri, A., Kuwabara, T., \& H Gage, F. (2006). Noncoding RNAs in the mammalian central nervous system. Annual review of neuroscience (Vol. 29). https://doi.org/10.1146/annurev.neuro.29.051605.112 839

Chang, Y., Kong, Q., Shan, X., Tian, G., Ilieva, H., Cleveland, D. W., ... Lin, C.G. (2008). Messenger RNA Oxidation Occurs Early in Disease Pathogenesis and Promotes Motor Neuron Degeneration in ALS. PLOS ONE, 3(8), e2849. https://doi.org/10.1371/journal.pone.0002849

Chen, Z., Wen, L., Martin, M., Hsu, C.Y., Fang, L., Lin, F.M., ... Shyy, J.Y.J. (2015). Oxidative stress activates endothelial innate immunity via sterol regulatory element binding protein 2 (SREBP2) transactivation of MicroRNA-92a. Circulation, 131(9), 805-814. https://doi.org/10.1161/CIRCULATIONAHA.114.013675

Cheng, Y., Liu, X., Zhang, S., Lin, Y., Yang, J., \& Zhang, C. (2009). MicroRNA-21 protects against the $\mathrm{H} 2 \mathrm{O} 2$-induced injury on cardiac myocytes via its target gene PDCD4. Journal of Molecular and Cellular Cardiology, 47(1), 5-14. https://doi.org/10.1016/j.yjmcc.2009.01.008

Dalle-Donne, I., Aldini, G., Carini, M., Colombo, R., Rossi, R., \& Milzani, A. (2006). Protein carbonylation, cellular dysfunction, and disease progression. Journal of Cellular and Molecular Medicine, 10(2), 389-406. https://doi.org/10.1111/j.1582-4934.2006.tb00407.x

Das, A., lanakiev, P., Baten, A., Nehleen, R., Ehsan, T., Ahmed, O., ... Khan, H. (2018). Genome of Tenualosa ilisha from the river Padma, Bangladesh. BMC Research Notes, 11(1), 921. https://doi.org/10.1186/s13104-018-4028-8

Devasagayam, T.P.A., Tilak, J.C., Boloor, K.K., Sane, K.S., Ghaskadbi, S.S., \& Lele, R.D. (2004). Free radicals and antioxidants in human health: current status and future prospects. The Journal of the Association of Physicians of India, 52, 794-804. Retrieved from http://www.ncbi.nlm.nih.gov/pubmed/15909857

Dhahri, W., Dussault, S., Haddad, P., Turgeon, J., Tremblay, S., Rolland, K., ... Rivard, A. (2017). Reduced expression of let-7f activates TGF-\$ $\beta \$ / A L K 5$ pathway and leads to impaired ischaemia-induced neovascularization after cigarette smoke exposure. Journal of Cellular and Molecular Medicine, 21(9), 2211-2222. https://doi.org/10.1111/jcmm.13144

DoF. (2019). Department of Fisheries (DoF), Bangladesh. Dhaka, Bangladesh: Ministry of Fisheries and Livestock.

Du, Y., Chi, X., \& An, W. (2019). Downregulation of microRNA$200 c-3 p$ reduces damage of hippocampal neurons in epileptic rats by upregulating expression of RECK and inactivating the AKT signaling pathway. ChemicoBiological Interactions, 307, 223-233. https://doi.org/10.1016/j.cbi.2019.04.027

Ekambaram, P., Narayanan, M., \& Jayachandran, T. (2014). Changes in oxidative stress and antioxidant status in stressed fish brain. International Journal of Science and Research, 3(5), 164-170. 
Felsenstein, J. (1985). Confidence Limits on Phylogenies: An Approach Using the Bootstrap. Evolution, 39(4), 783. https://doi.org/10.2307/2408678

Flynt, A.S., Thatcher, E.J., Burkewitz, K., Li, N., Liu, Y., \& Patton, J.G. (2009). miR-8 microRNAs regulate the response to osmotic stress in zebrafish embryos. Journal of Cell Biology, 185(1), 115-127. https://doi.org/10.1083/jcb.200807026

Forman, J.J., Legesse-Miller, A., \& Coller, H.A. (2008). A search for conserved sequences in coding regions reveals that the let-7 microRNA targets Dicer within its coding sequence. Proceedings of the National Academy of Sciences of the United States of America, 105(39), 14879-14884.

https://doi.org/10.1073/pnas.0803230105

FRSS. (2018). Yearbook of Fisheries Statistics of Bangladesh 2017-18. Ministry of Fisheries and Livestock Government of the People's Republic of Bangladesh. Dhaka: Fisheries Resources Survey System (FRSS), Retrieved from www.fisheries.gov.bd

Goodale, B.C., Hampton, T.H., Ford, E.N., Jackson, C.E., Shaw, J.R., Stanton, B.A., \& King, B.L. (2019). Profiling microRNA expression in Atlantic killifish (Fundulus heteroclitus) gill and responses to arsenic and hyperosmotic stress. Aquatic Toxicology, 206(November 2018), 142-153. https://doi.org/10.1016/j.aquatox.2018.11.009

Gupta, B. (2014). The Attributes of RNA Interference in Relation to Plant Abiotic Stress Tolerance. Gene Technology, 03(01), 1-4. https://doi.org/10.4172/23296682.1000110

Hairul-islam, V.I., Saravanan, S., Sekar, D., \& Karikalan, K. (2014). Identification of microRNAs from Atlantic salmon macrophages upon Aeromonas salmonicida infection. Rna \& Disease, 1-8. https://doi.org/10.14800/rd.303

Huang, C.X., Chen, N., Wu, X.J., He, Y., Huang, C.H., Liu, H., ... Wang, H.L. (2017). Zebrafish let-7b acts downstream of hypoxia-inducible factor- $1 \alpha$ to assist in hypoxiamediated cell proliferation and cell cycle regulation. Life Sciences, 171, 21-29.

https://doi.org/10.1016/j.lfs.2017.01.005

Hung, I.C., Hsiao, Y.C., Sun, H.S., Chen, T.M., \& Lee, S.J. (2016). MicroRNAs regulate gene plasticity during cold shock in zebrafish larvae. BMC Genomics, 17(1), 1-18. https://doi.org/10.1186/s12864-016-3239-4

Huo, D., Sun, L., Li, X., Ru, X., Liu, S., Zhang, L., ... Yang, H. (2017). Differential expression of miRNAs in the respiratory tree of the sea cucumber Apostichopus japonicus under hypoxia stress. G3: Genes, Genomes, Genetics, 7(11), 3681-3692.

https://doi.org/10.1534/g3.117.1129

Ischiropoulos, H. (2008). Protein tyrosine nitration-An update. Archives of biochemistry and biophysics (Vol. 484). https://doi.org/10.1016/j.abb.2008.10.034

Kolpa, H.J., Peal, D.S., Lynch, S.N., Giokas, A.C., Ghatak, S., Misra, S., ... Milan, D.J. (2013). miR-21 represses Pdcd4 during cardiac valvulogenesis. Development (Cambridge, England), 140(10), 2172-2180.

https://doi.org/10.1242/dev.084475

Kong, Q., \& Lin, C.-L.G. (2010). Oxidative damage to RNA: mechanisms, consequences, and diseases. Cellular and Molecular Life Sciences: CMLS, 67(11), 1817-1829. https://doi.org/10.1007/s00018-010-0277-y

Kumar, S., Stecher, G., Li, M., Knyaz, C., \& Tamura, K. (2018). MEGA X: Molecular Evolutionary Genetics Analysis across Computing Platforms. Molecular Biology and Evolution, 35(6), 1547-1549.

https://doi.org/10.1093/molbev/msy096

Kure, E.H., Sæb $\varnothing$, M., Stangeland, A.M., Hamfjord, J., Hytter $\varnothing d$, S., Heggenes, J., \& Lydersen, E. (2013). Molecular responses to toxicological stressors: Profiling microRNAs in wild atlantic salmon (Salmo salar) exposed to acidic aluminum-rich water. Aquatic Toxicology, 138-139, 98104. https://doi.org/10.1016/j.aquatox.2013.04.004

Lai, K.P., Li, J.W., Tse, A.C.K., Chan, T.F., \& Wu, R.S.S. (2016). Hypoxia alters steroidogenesis in female marine medaka through miRNAs regulation. Aquatic Toxicology, 172, 18. https://doi.org/10.1016/j.aquatox.2015.12.012

Lau, K., Lai, K.P., Bao, J.Y.J., Zhang, N., Tse, A., Tong, A., ... Wu, R.S.S. (2014). Identification and expression profiling of MicroRNAs in the brain, liver and gonads of marine medaka (Oryzias melastigma) and in response to hypoxia. PLOS ONE, 9(10), 7-8. https://doi.org/10.1371/journal.pone.0110698

Leung, A.K.L., \& Sharp, P.A. (2010). MicroRNA functions in stress responses. Molecular Cell, 40(2), 205-215. https://doi.org/10.1016/j.molcel.2010.09.027

Lewis, B.P., Burge, C.B., \& Bartel, D.P. (2005). Conserved Seed Pairing, Often Flanked by Adenosines, indicates that Thousands of Human Genes are MicroRNA Targets. Cell, 120(1), 15-20. https://doi.org/10.1016/j.cell.2004.12.035

Li, C., \& Xu, D. (2018). Understanding microRNAs regulation in heat shock response in the sea cucumber Apostichopus japonicus. Fish and Shellfish Immunology, 81(700), 214220. https://doi.org/10.1016/j.fsi.2018.07.034

Li, X.H., Wu, J.S., Tang, L.H., \& Hu, D. (2015). Identification of conserved microRNAs and their target genes in Nile tilapia (Oreochromis niloticus) by bioinformatic analysis. Genetics and Molecular Research, 14(1), 2785-2792. https://doi.org/10.4238/2015.March.31.8

Lin, Y., Liu, X., Cheng, Y., Yang, J., Huo, Y., \& Zhang, C. (2009). Involvement of MicroRNAs in hydrogen peroxidemediated gene regulation and cellular injury response in vascular smooth muscle cells. The Journal of Biological Chemistry, 284(12), 7903-7913. https://doi.org/10.1074/jbc.M806920200

Liu, G., Li, Y., \& Gao, X.G. (2016). MicroRNA-181a is upregulated in human atherosclerosis plaques and involves in the oxidative stress-induced endothelial cell dysfunction through direct targeting Bcl-2. European Review for Medical and Pharmacological Sciences, 20(14), 3092-3100.

Liu, X., Zhang, Z., Sun, L., Chai, N., Tang, S., Jin, J., ... Fan, D. (2011). microRNA-499-5p promotes cellular invasion and tumor metastasis in colorectal cancer by targeting FOXO4 and PDCD4. Carcinogenesis, 32(12), 1798-1805. https://doi.org/10.1093/carcin/bgr213

Lu, Z., Liu, M., Stribinskis, V., Klinge, C.M., Ramos, K.S., Colburn, N.H., \& Li, Y. (2008). MicroRNA-21 promotes cell transformation by targeting the programmed cell death 4 gene. Oncogene, 27(31), 4373-4379. https://doi.org/10.1038/onc.2008.72

Lushchak, V.I. (2011). Adaptive response to oxidative stress: Bacteria, fungi, plants and animals. Comparative Biochemistry and Physiology Part C: Toxicology \& Pharmacology, 153(2), 175-190. https://doi.org/10.1016/j.cbpc.2010.10.004 
Ma, F., Liu, Z., Huang, J., Li, Y., Kang, Y., Liu, X., \& Wang, J. (2019). High-throughput sequencing reveals microRNAs in response to heat stress in the head kidney of rainbow trout (Oncorhynchus mykiss). Functional and Integrative Genomics. https://doi.org/10.1007/s10142-019-006823

Ma, J., Chen, X., Xin, G., \& Li, X. (2019). Chronic exposure to the ionic liquid [C $8 \mathrm{mim}$ ] $\mathrm{Br}$ induces inflammation in silver carp spleen: Involvement of oxidative stress-mediated p38MAPK/NF-KB signalling and microRNAs. Fish and Shellfish Immunology, 84(June 2018), 627-638. https://doi.org/10.1016/j.fsi.2018.09.052

Magenta, A., Cencioni, C., Fasanaro, P., Zaccagnini, G., Greco, S., Sarra-Ferraris, G., ... Capogrossi, M.C. (2011a). miR$200 \mathrm{c}$ is upregulated by oxidative stress and induces endothelial cell apoptosis and senescence via ZEB1 inhibition. Cell Death and Differentiation, 18(10), 16281639. https://doi.org/10.1038/cdd.2011.42

Magenta, A., Cencioni, C., Fasanaro, P., Zaccagnini, G., Greco, S., Sarra-Ferraris, G., ... Capogrossi, M.C. (2011b). MiR$200 \mathrm{c}$ is upregulated by oxidative stress and induces endothelial cell apoptosis and senescence via ZEB1 inhibition. Cell Death and Differentiation, 18(10), 16281639. https://doi.org/10.1038/cdd.2011.42

McWilliam, H., Li, W., Uludag, M., Squizzato, S., Park, Y.M., Buso, N., ... Lopez, R. (2013). Analysis Tool Web Services from the EMBL-EBI. Nucleic Acids Research, 41(Web Server issue), W597--600 https://doi.org/10.1093/nar/gkt376

Mohanta, M.K., Saha, A.K., Hasan, A., \& Roy, A.K. (2010). Effects of Tannery Effluents on Survival and Histopathological Changes in Different Organs of Channa punctatus. Asian Journal of Experimental Biological Sciences, 1(2), 294-302.

Morii, K., Yamasaki, S., Doi, S., Irifuku, T., Sasaki, K., Doi, T., ... Masaki, T. (2019). MicroRNA-200c regulates KLOTHO expression in human kidney cells under oxidative stress. PLOS ONE, 14(6). https://doi.org/10.1371/journal.pone.0218468

Peterson, S.M., \& Freeman, J.L. (2009). RNA isolation from embryonic zebrafish and cDNA synthesis for gene expression analysis. Journal of Visualized Experiments: JoVE, (30). https://doi.org/10.3791/1470

Qiang, J., Bao, W.J., Tao, F.Y., He, J., Li, X.H., Xu, P., \& Sun, L.Y. (2017). The expression profiles of miRNA-mRNA of early response in genetically improved farmed tilapia (Oreochromis niloticus) liver by acute heat stress. Scientific Reports, 7(1). https://doi.org/10.1038/s41598017-09264-4

Qiang, J., Cui, Y.T., Tao, F.Y., Bao, W.J., He, J., Li, X.H., ... Sun, L.Y. (2018). Physiological response and microRNA expression profiles in head kidney of genetically improved farmed tilapia (GIFT, Oreochromis niloticus) exposed to acute cold stress. Scientific Reports, 8(1). https://doi.org/10.1038/s41598-017-18512-6

Qiang, J., Tao, F., Bao, W., He, J., Liang, M., Liang, C., ... Xu, P. (2019). miR-489-3p Regulates the Oxidative Stress Response in the Liver and Gill Tissues of Hybrid Yellow Catfish (Pelteobagrus fulvidraco $\times P$. vachellio') Under $\mathrm{Cu} 2+$ Exposure by Targeting $\mathrm{Cu} / \mathrm{Zn}-\mathrm{SOD}$. Frontiers in Physiology, 10(July), 1-13. https://doi.org/10.3389/fphys.2019.00868

Qiang, J., Tao, Y.F., He, J., Sun, Y.L., \& Xu, P. (2017). MiR-29a modulates SCD expression and is regulated in response to a saturated fatty acid diet in juvenile genetically improved farmed tilapia (Oreochromis niloticus). Journal of Experimental Biology, 220(8), 1481-1489. https://doi.org/10.1242/jeb.151506

Safran, M., Dalah, I., Alexander, J., Rosen, N., Iny Stein, T., Shmoish, M., ... Lancet, D. (2010). GeneCards Version 3: the human gene integrator. Database, 2010(0), baq020 -baq020. https://doi.org/10.1093/database/baq020

Saitou, N., \& Nei, M. (1987). The neighbor-joining method: a new method for reconstructing phylogenetic trees. Molecular Biology and Evolution, 4, 406-425. https://doi.org/10.1093/oxfordjournals.molbev.a04045 4

Saleh, A.D., Savage, J.E., Cao, L., Soule, B.P., Ly, D., DeGraff, W., ... Simone, N.L. (2011). Cellular stress induced alterations in microrna let-7a and let-7b expression are dependent on p53. PLOS ONE, 6(10). https://doi.org/10.1371/journal.pone.0024429

Schnall-Levin, M., Zhao, Y., Perrimon, N., \& Berger, B. (2010). Conserved microRNA targeting in Drosophila is as widespread in coding regions as in $3^{\prime}$ UTRs. Proceedings of the National Academy of Sciences of the United States of America, 107(36), 15751-15756. https://doi.org/10.1073/pnas.1006172107

Shahidul Islam, M., \& Tanaka, M. (2004). Impacts of pollution on coastal and marine ecosystems including coastal and marine fisheries and approach for management: a review and synthesis. Marine Pollution Bulletin, 48(7-8), 624-649. https://doi.org/10.1016/J.MARPOLBUL.2003.12.004

Simone, N.L., Soule, B.P., Ly, D., Saleh, A.D., Savage, J.E., DeGraff, W., ... Mitchell, J.B. (2009). Ionizing radiationinduced oxidative stress alters miRNA expression. PLOS ONE, 4(7), 1-7. https://doi.org/10.1371/journal.pone.0006377

Sun, J.L., Liu, Q., Zhao, L.L., Cui, C., Wu, H., Liao, L., ... Yang, S. (2019). Potential regulation by miRNAs on glucose metabolism in liver of common carp (Cyprinus carpio) at different temperatures. Comparative Biochemistry and Physiology - Part D: Genomics and Proteomics, 32(October), 100628. https://doi.org/10.1016/j.cbd.2019.100628

Sun, J.L., Zhao, L.L., Wu, H., Lian, W.Q., Cui, C., Du, Z.J., ... Yang, S. (2019). Analysis of miRNA-seq in the liver of common carp (Cyprinus carpio L.) in response to different environmental temperatures. Functional and Integrative Genomics, 19(2), 265-280. https://doi.org/10.1007/s10142-018-0643-7

Tamura, K., Nei, M., \& Kumar, S. (2004). Prospects for inferring very large phylogenies by using the neighbor-joining method. Proceedings of the National Academy of Sciences of the United States of America, 101(30), 11030-11035. https://doi.org/10.1073/pnas.0404206101

Tang, X.-L., Xu, M.-J., Li, Z.-H., Pan, Q., \& Fu, J.-H. (2013). Effects of vitamin $\mathrm{E}$ on expressions of eight microRNAs in the liver of Nile tilapia (Oreochromis niloticus). Fish \& Shellfish Immunology, 34(6), 1-6. https://doi.org/10.1016/j.fsi.2013.03.353

Tian, Y., Shang, Y., Guo, R., Chang, Y., \& Jiang, Y. (2019). Salinity stress-induced differentially expressed miRNAs and target genes in sea cucumbers Apostichopus japonicus. Cell Stress and Chaperones, 24(4), 719-733. https://doi.org/10.1007/s12192-019-00996-y

Topal, A., Atamanalp, M., Oruç, E., \& Erol, H.S. (2017). Physiological and biochemical effects of nickel on 
rainbow trout (Oncorhynchus mykiss) tissues: Assessment of nuclear factor kappa B activation, oxidative stress and histopathological changes. Chemosphere, 166, 445-452. https://doi.org/10.1016/j.chemosphere.2016.09.106

Tse, A.C.-K., Li, J.-W., Chan, T.-F., Wu, R.S.-S., \& Lai, K.-P. (2015). Hypoxia induces miR-210, leading to anti-apoptosis in ovarian follicular cells of marine medaka Oryzias melastigma. Aquatic Toxicology (Amsterdam, Netherlands), 165, 189-196. https://doi.org/10.1016/j.aquatox.2015.06.002

Tse, W.K.F. (2014). The role of osmotic stress transcription factor 1 in fishes. Frontiers in Zoology, 11(1), 86. https://doi.org/10.1186/s12983-014-0086-5

Tu, H., Sun, H., Lin, Y., Ding, J., Nan, K., Li, Z., ... Wei, Y. (2014). Oxidative Stress Upregulates PDCD4 Expression in Patients with Gastric Cancer via miR-21. Current Pharmaceutical Design, 20(11), 1917-1923.

Ulitsky, I., Shkumatava, A., Jan, C.H., Subtelny, A.O., Koppstein, D., Bell, G.W., ... Bartel, D.P. (2012). Extensive alternative polyadenylation during zebrafish development. Genome Research, 22(10), 2054-2066.

https://doi.org/10.1101/gr.139733.112

UniProt: a hub for protein information. (2015). Nucleic Acids Research, 43(D1), D204--D212. https://doi.org/10.1093/nar/gku989

Van Rooij, E., Sutherland, L.B., Qi, X., Richardson, J.A., Hill, J., \& Olson, E.N. (2007). Control of stress-dependent cardiac growth and gene expression by a microRNA. Science, 316(5824), 575-579.

https://doi.org/10.1126/science.1139089

Vasadia, D.J., Zippay, M.L., \& Place, S.P. (2019). Characterization of thermally sensitive miRNAs reveals a central role of the FoxO signaling pathway in regulating the cellular stress response of an extreme stenotherm, Trematomus bernacchii. Marine Genomics. https://doi.org/10.1016/j.margen.2019.100698

Wan, C., Han, R., Liu, L., Zhang, F., Li, F., Xiang, M., \& Ding, W. (2016). Role of miR-155 in fluorooctane sulfonateinduced oxidative hepatic damage via the Nrf2dependent pathway. Toxicology and Applied Pharmacology, 295, 85-93.

https://doi.org/10.1016/j.taap.2016.01.023

Wang, K., Gan, T.Y., Li, N., Liu, C.Y., Zhou, L.Y., Gao, J.N., ... Li, P.F. (2017). Circular RNA mediates cardiomyocyte death via miRNA-dependent upregulation of MTP18 expression. Cell Death and Differentiation, 24(6), 11111120. https://doi.org/10.1038/cdd.2017.61

Wang, L., Huang, H., Fan, Y., Kong, B., Hu, H., Hu, K., ... Liu, W.L. (2014). Effects of downregulation of microrna-181a on h2O 2-induced H9c2 Cell apoptosis via the mitochondrial apoptotic pathway. Oxidative Medicine and Cellular Longevity, 2014. https://doi.org/10.1155/2014/960362

Wang, W., Hang, C., Zhang, Y., Chen, M., Meng, X., Cao, Q., ... Yu, D. (2017). Dietary miR-451 protects erythroid cells from oxidative stress via increasing the activity of Foxo3 pathway. Oncotarget, 8(63), 107109-107124. https://doi.org/10.18632/oncotarget.22346

Wang, Y., Cheng, K., Zhou, W., Liu, H., Yang, T., Hou, P., \& Li, X. (2019). miR-141-5p regulate ATF2 via effecting MAPK1/ERK2 signaling to promote preeclampsia. Biomedicine and Pharmacotherapy, 115. https://doi.org/10.1016/j.biopha.2019.108953

Wei, C., Li, L., Kim, I.K., Sun, P., \& Gupta, S. (2014). NF-kB mediated miR-21 regulation in cardiomyocytes apoptosis under oxidative stress. Free Radical Research, 48(3), 282-291.

https://doi.org/10.3109/10715762.2013.865839

Winston, G.W. (1991). Oxidants and antioxidants in aquatic animals. Comparative Biochemistry and Physiology Part C: Comparative Pharmacology, 100(1-2), 173-176. https://doi.org/10.1016/0742-8413(91)90148-M

Xu, Z., Chen, J., Li, X., Ge, J., Pan, J., \& Xu, X. (2013). Identification and characterization of microRNAs in channel catfish (Ictalurus punctatus) by using Solexa sequencing technology. PloS One. Retrieved from http://journals. plos.org/plosone/article?id=10.1371/jou rnal.pone.0054174

Yan, B., Guo, J.T., Zhao, L.H., \& Zhao, J.L. (2012). MiR-30c: A novel regulator of salt tolerance in tilapia. Biochemical and Biophysical Research Communications, 425(2), 315320. https://doi.org/10.1016/j.bbrc.2012.07.088

Yan, B., Zhao, L.H., Guo, J.T., \& Zhao, J.L. (2012). MiR-429 regulation of osmotic stress transcription factor 1 (OSTF1) in tilapia during osmotic stress. Biochemical and Biophysical Research Communications, 426(3), 294-298. https://doi.org/10.1016/j.bbrc.2012.08.029

Yang, R., Dai, Z., Chen, S., \& Chen, L. (2011). MicroRNAmediated gene regulation plays a minor role in the transcriptomic plasticity of cold-acclimated zebrafish brain tissue. BMC Genomics, 12(1), 605. https://doi.org/10.1186/1471-2164-12-605

Yang, S., Luo, J., Long, Y., Du, J., Xu, G.C., Zhao, L., ... He, Z. (2019). Mixed Diets Reduce the Oxidative Stress of Common Carp (Cyprinus carpio): Based on microRNA sequencing. Frontiers in Physiology, 10(MAY). https://doi.org/10.3389/fphys.2019.00631

Yang, T., Cao, C., Yang, J., Liu, T., Lei, X.G., Zhang, Z., \& Xu, S. (2018). miR-200a-5p regulates myocardial necroptosis induced by Se deficiency via targeting RNF11. Redox Biology, 15, 159-169. https://doi.org/10.1016/j.redox.2017.11.025

Yu, D., Dos Santos, C.O., Zhao, G., Jiang, J., Amigo, J.D., Khandros, E., ... Weiss, M.J. (2010). miR-451 protects against erythroid oxidant stress by repressing 14-3-3?? Genes and Development, 24(15), 1620-1633. https://doi.org/10.1101/gad.1942110

Zhang, G., Yin, S., Mao, J., Liang, F., Zhao, C., Li, P., ... Tang, Z. (2016). Integrated analysis of mRNA-seq and miRNA-seq in the liver of Pelteobagrus vachelli in response to hypoxia. Scientific Reports, 6(March), 1-12. https://doi.org/10.1038/srep22907

Zhang, Q., Zheng, S., Wang, S., Wang, W., Xing, H., \& Xu, S. (2019). Chlorpyrifos induced oxidative stress to promote apoptosis and autophagy through the regulation of miR19a-AMPK axis in common carp. Fish \& Shellfish Immunology, 93, 1093-1099. https://doi.org/10.1016/j.fsi.2019.07.022

Zhao, Y., Wu, J.-W., Wang, Y., \& Zhao, J.-L. (2016). Role of miR21 in alkalinity stress tolerance in tilapia. Biochemical and Biophysical Research Communications, 471(1), 2633. https://doi.org/10.1016/j.bbrc.2016.02.007

Zhao, Y., Zhu, C.D., Yan, B., Zhao, J.L., \& Wang, Z.H. (2014). miRNA-directed regulation of VEGF in tilapia under hypoxia condition. Biochemical and Biophysical Research Communications, 454(1), 183-188. https://doi.org/10.1016/j.bbrc.2014.10.068

Zheng, J., Cao, J., Mao, Y., Su, Y., \& Wang, J. (2018). Identification of microRNAs with heat stress responsive and immune properties in Marsupenaeus japonicus 
based on next-generation sequencing and bioinformatics analysis: Essential regulators in the heat stress-host interactions. Fish and Shellfish Immunology, 81, 390-398. https://doi.org/10.1016/j.fsi.2018.05.030
Zhou, C.Q., Zhou, P., Ren, Y.L., Cao, L.H., \& Wang, J.L. (2019). Physiological response and miRNA-mRNA interaction analysis in the head kidney of rainbow trout exposed to acute heat stress. Journal of Thermal Biology, 83(222), 134-141.

https://doi.org/10.1016/j.jtherbio.2019.05.014 